\title{
The Role of Audit Committee in Enhancing Financial Reporting In Nigeria
}

\author{
Atu, Oghogho Gina, Atu,Omimi-Ejoor Osaretin Kingsley, \\ Atu, Osahenoma Vivian, Abusomwan Rachael Eloho \\ Audit Senior Atu, Omimi-Ejoor Osaretin \& Co. (Chartered Accountants)M.Sc Student, Igbinedion University, \\ Okada \\ (Aca,Fcma,Acti,Aat,Mba,M.Sc,Pdg,Comp.Sc; Dipl.)Lecturer: Igbinedion University, Okada.Edo State, Nigeria- \\ West Africa \\ Audit Senior Atu, Omimi-Ejoor Osaretin \& Co.(Chartered Accountants) .O Box 9006 M.Sc Student, Igbinedion \\ University, Okada \\ Lecturer: Benson Idahosa University. Edo State, Nigeria-West Africa
}

\begin{abstract}
This research paper is centered on the role of Audit committee in enhancing financial reporting in Nigeria which has now become a very important issue in the accounting profession in light of the various accounting scandals. The objectives of this research is to examine the extent to which the inclusion of the audit committee report in the financial statement significantly affects the quality of financial reporting, examine the extent to which the qualification of audit committee member affects its report and examine the extent to which audit committee multiple directorships affect the function of the committee. To answer the research question put forward in this paper sample size of 50 respondents was selected. The data was analyzed using the Z-Test with the computer software known as SPSS and it was found out that audit committee report in the financial statement significantly affects the quality of financial reporting, the qualification of audit committee members, according to users' perception, adds to the quality of the financial statement and Audit committee multiple directorship have positive effect on the function of the audit committee. It was concluded that the importance of audit committee is immerse and as such stakeholders of public limited companies should take extra care in setting up the committee.
\end{abstract}

Keywords: Audit Committee, Audit Committee Multiple Directorship And Financial Reports

\section{Introduction}

The growth of the Audit and Accountancy Profession, both in status and in numbers has been greatly accelerated by the ever-increasing complexity of commercial and industrial. Every private and public Limited Company must, by law have an annual audit. While no legal compulsion is placed on the proprietors of partnership or on sole traders to engage the services professional Auditors, an increasing number of individuals and enterprises are realizing the benefits to be obtained from a periodic Audit (Author 1907)

Over the years, Financial Statement have grown considerably in size and importance following the rapidly changing socio-political and economic environment. Such statement include, among others, the Balance Sheet now called Statement of Financial Position, the Profit and Loss Account now called statement comprehensive income, Value Added Statement, Cash-Flow statement, Five-year Financial Summary etc; and they are prepared and presented in accordance with certain Generally Accepted Principles, rules, procedures etc which apply globally (Anyaduba 1996).

The financial statement as prepared by company directors is a statutory report, conveying both qualitative and quantitative information to assist users of accounting information in making informed decisions. As a statement that serves multiplicity of users, the financial statement meets the general needs of users (Enofe Aronmwan \& Abadua, 2013). Prior to companies and Allied Matters Acts, 1900, there were no statutory provisions for the compulsory Audit of a company's financial statement. As many companies, realizing the necessity for protecting the interest of the investing public, they inserted a clause in their Article of Association, for the preparation of Annual audit by an independent persons. In the light of this Auditing can be defined as; "The independent critical examination of and an expression of opinion on, the financial statement and underlying records of an enterprise by an appointed Auditor. In pursuance of the Audit objective, the preparation of the financial statements is the responsibility of the management. The responsibility of the auditor is to report on the financial statement as presented by the management"

\section{Statement Of Problem}

Audit committees have been in existence since the year 1939 Armitage \&Brandley (1994). However, there have being several criticisms as to the importance of audit committee in enhancing financial reporting. For 
financial statement to be useful for decision making it must show the true and fair view of the company statements of financial position and performance. This can only be achieved through regular and periodic audit of the company financial statements as prepared by the auditors. However this audit by independent auditors has over the years due to corporate failures lost its full potential and as such pave way for this same auditors to be check mated by an independent committee called the audit committee. Audit committee's definition according to companies and allied Matters Act 2004 section 359 subsection 4 states that "Audit committee shall consist of an equal number of directors and representatives of the share-holders of the company (subject to maximum number of six members) and shall examine the Auditor report and make recommendations thereof on the Annual General Meetings it may think fit, provided, however, that such member of the audit committee shall not be entitled to remuneration and shall be subject to re-election annually". As mentioned in the literature review there are numbers of studies on Audit committee that have being conducted even in Nigeria. However, the findings of those researchers are different from each other as well as inconclusive. Different studies paid attention on different ideals some of this researchers include Enofe Aronmwan \& Abadua, 2013; MuhamadSori, Abdul-Hamid, Mohd-Saad, \& Evans (2007); Anyaduba (2006), Ayinde (2002), Urbancic (1991), Adeyemi, Okpala \& Dabor (2012) Kenneth (2012). Among the available published researches, the researcher is not aware of any that has examines the effects of the composition of audit committee on its report and the effect of the qualification of audit committee members on its report. However the researcher added to its objective the extent to which audit committee report enhances the quality of financial reporting in Nigeria. Therefore, the study fills the gap in literature by investigating the role of Audit committee in enhancing financial reporting in Nigeria relation to quantification of committee members, Compositions and multiple audit committee directorship.

In view of the above the objective of the research can thus be stated as follows:

1. Examine the extent to which the inclusion of the audit committee report in the financial statement significantly affects the quality of financial reporting

2. Examine the extent to which the qualification of audit committee member affects its report

3. Examine the extent to which audit committee multiple directorships affect the function of the committee.

From the above objectives the research question can be drawn which are:

1. To what extent does the inclusion of the audit committee report in the financial statement significantly affects the quality of financial reporting

2. To what extent does the quantification of audit committee member affects its report

3. To what extent does audit committee multiple directorship affects the function of the committee.

\section{Literature Review}

An audit committee according to S 359 (4) CAMA 2004 C20 LFN is an operating committee of the Board of Directors charged with oversight responsibility of financial reporting and disclosure. Audit committee is viewed as a committee (or equivalent body) established by and amongst the board of directors of an issuer for the purpose of overseeing the accounting and financial reporting processes of the issuer and audits of the financial statements of the issuer (SOX 2002). In another view, Ayinde (2002) opines that the audit committee is a standing committee established to enhance corporate accountability by working with the internal auditors and management to improve and strengthen the financial reporting practices of an entity and ensure proper conduct of corporate affairs in accordance with generally accepted ethical and legal standards. Audit committee is made up of an equal number of directors and shareholders. This enables it to effectively check the powers of the executive directors, with particular reference to the accounting and financial reporting functions. It further strengthens the reporting functions as it enhances the independence of auditors by allowing them to report to a body that is independent of the executive directors ( Enofe et al, 2013).

Audit committee internally audit the auditors and make a report that are usually included in the financial statement of a publicly quoted companies in accordance with section 359 sub section 4 and are usually consist of 6 members.

Audit committees serve as a bridge in the communication network between internal and external auditors and the board of directors. Audit committee helps to check the activities of the auditors ( both internal and external ) and top management resulting to the bridging of the gap among users of financial statements.

The development of audit committees can be divided according to Enofe et al (2013) basically into two periods: voluntary establishment period and mandatory establishment period. The former was prior to 1970 while the latter is subsequent to 1970. According to the Canadian Institute of Chartered Accountants [CICA] (1981), Canada was the first country to legally introduce Audit committees after which, the USA followed suits In 1970. But in In 1978, as the pressure from the public as well as Security and Exchange Commission (SEC) mounted for public companies to be mandated to establish audit committees, they became a part of requirements for listing on the New York Stock Exchange (NYSE). 
In Nigeria, Professor Olowokure of the University of Maiduguri, 1989 published a two-part article Title A Case for Audit committees in Nigeria" in "The Nigeria accountants"; for the need to set up Audit committees for publicly quoted companies in Nigeria as a means of restoring the credibility of Financial Reporting ( Nnadi 1999). Today, all over the world publicly traded companies maintain Audit committee. In Nigeria this was provided for in section 359 subsection 3 CAMA 1990 (companies and Allied Matters Act 1990) for external Auditors to report to an Audit committee.

The idea of having Audit Committees has largely arisen because of fears over recent years about the possible erosion of Auditors Independence, and criticism of the way in which non-executive directors of companies carry out their duties which has led to the collapse of major organizations some of which are :Atlantic Acceptance Corporation Ltd., Penn Central Company... just to mention a few. Thus, the Audit Committee can be viewed as a way of preserving auditor independence (by, for example, helping to resolve contentions issues between the Auditor and Company Management), and a means of providing non-executive directors with a better working knowledge of the Company's business operations (Millichamp 1978). More so the main role and responsibilities of Audit committee according to Smith (2003) should be:

- To monitor the integrity of the financial statements of the company;

- To review the company's internal financial control system and, unless addressed by a separate risk committee or by the board itself, risk management systems;

- To monitor and review the effectiveness of the company's internal audit function;

- To make recommendations to the board in relation to the appointment of the external auditor and to approve the remuneration and terms of engagement of the external auditor following appointment by the shareholders in general meeting;

- To monitor and review the external auditor's independence, objectivity and effectiveness;

- To develop and implement policy on the engagement of the external auditor to supply non-audit services. Where the audit committee's monitoring and review activities reveal cause for concern or scope for improvement, it should make recommendations to the board on action needed to address the issue or to make improvements.

Most importantly to increase public confidence in Financial Information be that as it may, "it is not sufficient for a company to establish an Audit Committee just to satisfy the letters of the Companies' Act. The company and its board of directors must show full commitment to corporate accountability by providing conducive environment in which their audit Committee can discharge its responsibilities efficiently and effectively". ( Ekwueme 2000).

The committee benefits according to Kenneth (2012) are: (i) assist in establishing and strengthening the independence and objectivity of the directors and the internal and external auditors (ii) there will be improved communication and increased contact, understanding and confidence between directors, management and the internal and external auditors (iii) increased internal and external auditors' accountability as their performance are under greater scrutiny (iv) help to create a climate of discipline and control which reduces the opportunity for fraud (v) Result in efficient and effective external audit and (vi) strengthening the objectivity and credibility of financial reporting. For proper discharge of duties,

\section{Qualification Of Audit Committee}

CAMA 2004 did not state the qualifications required of an audit committee member. This weakness in the law has led to less reliance in the committee report based on the fact that some of the member may have little or no ideal about the companies financial statement or company's policy. But With the nature of the functions the Audit Committee is charge with, it is apparent that the members of the committee would have to posses the appropriate qualifications to be able to carry them out effectively. A high degree of financial literacy is necessary for an audit committee to effectively oversee a company's financial control and reporting. The role of an audit committee in overseeing accountability of the management covers a wide scope to include the overall process of corporate reporting. This requires the audit committee to have accounting knowledge in order to acquire an in-depth understanding of financial reporting and improve compliance with regulatory requirements. The need to comprehend the overall financial and non-financial contents of corporate reports is greater considering that listed companies are operating as conglomerates with some having complex group structures and therefore, presenting technically advanced financial reporting contents. Financial literacy reduced fraud in corporate financial reporting Song \& Windram (2000). Kenneth (2012) was also with same view with Song \& Windram according to him for proper discharge of duties, all members of the committee should be financial literate and have understanding of the industry in which the company operates and at least one member have financial expertise and professional qualification of the recognized professional accounting bodies. When the audit committee carries out their responsibilities properly, the result is definitely a credible financial statement which is the basis for good corporate governance and corporate failures will be avoided. A formal recognition of this requirement was recently made in the U.S. with the passing of the Sarbanes-Oxley Act 
(2002) which requires each public listed company to disclose whether or not it has a financial expert in the audit committee.

\section{Multiple Directorships Of Audit Committee Members}

This can be defined as the number of director positions held by audit committee members (Shivdasani, 1993)). Song \& Windram (2000) argue that multiple directorship may cause limitations of time and commitment for audit committee members from performing effectively. Audit committee members who held directors' posts of too many companies may have limited time fulfilling their responsibilities. Ruzaidah \& Takiah (2004) in their study of Malaysia companies, found out the importance of experience audit committee members gained through director positions in other companies. They argued that multiple directorships of audit committee members was found to have significant positive relationship with corporate social reporting practices and corporate performance. In recent studies of Adeyemi, Okpala \& Dabor (2012), they were of the opinion that multiple directorships of audit committee members is a significant factor in explaining audit quality in Nigeria this might be due to the appointment of experienced directors as audit committee members. The directors might have gained a significant knowledge in understanding both the financial and non financial information contained in the annual reports and accounts of companies such that there were little or no difficulties in understanding and making intelligent interpretations of the accounts and the extent to which they fairly represent the underlying financial transactions from which they were prepared, thereby translating to a reasonable level of oversight function on the auditors. This suggests that audit committee with multiple directorships enhances the quality of financial reporting.

\section{Audit Committee Report}

The audit committee is expected to communicate to the stakeholders the outcome of their duties and functions. They do this via the report. According to SOX (2002), the term audit report is use to describe a document or record usually prepared after an audit assignment performed for purposes of compliance and determination of the true state of affairs of a company wherein a public accounting firm either expresses an opinion concerning the affairs of that company regarding its financial statement or asserts that no such opinion can be expressed. When such report is prepared by the audit committee as tailored to their responsibilities, it can then be seen as an audit committee report. According to CAMA, 1990 as amended, the chairman of the committee is expected to disclose the oversight function carried out as a separate report. According to Auditing and Assurance Standards Board, this report will normally have the following information:

- The audit committee's roles and responsibilities, structure and membership, and its principal activities during the year.

- Any resolutions and recommendation of the audit committee

- Information about the audit processes and the results of work carried out by the auditors

- Any observation of the audit committee about the external auditors' independence

\section{Methodology}

This paper relies on Primary data which consist of Questionnaire, Internet, Literature Review of the writings to expand in the field, extracted from Textbook and other relevant Publication. The sample of the study consist of the following companies: First Bank Plc, Sapale road branch Benin City; Access Bank plc, Okada Edo State; Guinness Nigeria Plc and Presco Industries Plc. A sample of (50) respondents was used. After the questionnaires were administered only 40 completed Questionnaires were received. The data gathered will be analyzed using the Z-Test with the computer software known as SPSS. The formula of the Z-test is given below:

$$
\begin{aligned}
& \mathrm{Z}=\mathrm{x}-\mathrm{nPo} \\
& \mathrm{nPo} \mathrm{x}(1-\mathrm{Po}) \\
& \text { Where } \mathrm{x}=\text { No. of agreed variables } \\
& \mathrm{n}=\text { total no. of samples (sample size) } \\
& \mathrm{Po}=\text { Probability of the null hypothesis }
\end{aligned}
$$

The $\mathrm{Z}$-test is any statistical test for which the distribution of the test statistic under the null hypothesis can be approximated by a normal distribution. For each significance level the $Z$ - test has a single critical value which makes it more convenient. Therefore, many statistical tests can conveniently be perform as approximate Z- Test if the sample size is large ( more than 30) or the Population Variance known. In this study the sample size is more than 30 hence the justification of the technique. 


\section{Test Of Hypotheses}

In testing the various hypotheses developed in this research, the $\mathrm{Z}$ test would be employed at 0.05 level of significance. We accept alternative hypotheses if the calculated value is greater than the table value and reject the null. We accept the null if the calculated is less than the table value.

\section{Test Of Hypothesis}

\section{HYPOTHESIS 1}

Ho: the inclusion of the audit committee report in the financial statement does not significantly affects the quality of financial reporting

Table of Responses: Table 4.2.1

\begin{tabular}{|l|l|l|}
\hline RESPONSES & NO & PERCENTAGE \\
\hline Agree & $\mathbf{5}$ & $\mathbf{1 2 . 5 \%}$ \\
\hline Disagree & $\mathbf{2 0}$ & $\mathbf{5 0 \%}$ \\
\hline Strongly Agree & 10 & $\mathbf{2 5 \%}$ \\
\hline Strongly Disagree & $\mathbf{5}$ & $\mathbf{1 2 . 5 \%}$ \\
\hline Total & $\mathbf{4 0}$ & $\mathbf{1 0 0}$ \\
\hline
\end{tabular}

Sources: Researcher's Survey 2013

The table of response was subjected to analysis using SPSS (16) and the Z-Test result is given below:

One-Sample Z- Test

\begin{tabular}{|ll|l|}
\hline & & Hypothesis One \\
\hline Normal Parameters ${ }^{\mathrm{a}}$ & & 40 \\
& Mean & 2.3750 \\
Most Extreme Differences & Std. Deviation & .86787 \\
& Absolute & .292 \\
& Positive & .292 \\
Z- Test & Negative & -.208 \\
Asymp. Sig. (2-tailed) & & 1.848 \\
a. Test distribution is Normal. & & .002 \\
\hline
\end{tabular}

Source: SPSS Output

From the SPSS output, it will be observed that Z-test calculated is 1.848 while $Z$ critical is 1.6448536 . Since the critical value at 1.64485 is less than the calculated $Z$ (1.848), the null hypothesis will be rejected and the alternative accepted. This implies that; the inclusion of the audit committee report in the financial statement significantly affects the quality of financial reporting

\section{HYPOTHESIS 11}

1. Ho: The qualification of audit committee member do not affect its report

Table 4.2.2

\begin{tabular}{|l|l|l|}
\hline RESPONSES & NO & PERCENTAGE \\
\hline Agree & 4 & $\mathbf{1 0 \%}$ \\
\hline Disagree & 20 & $\mathbf{5 0 \%}$ \\
\hline Strongly Agree & 6 & $\mathbf{1 5 \%}$ \\
\hline Strongly Disagree & 10 & $\mathbf{2 5 \%}$ \\
\hline Total & $\mathbf{4 0}$ & $\mathbf{1 0 0}$ \\
\hline
\end{tabular}

Sources: Researcher's Survey 2013

The table of response was subjected to analysis using SPSS (16) and the Z-Test result is given below:

\begin{tabular}{|ll|l|} 
One-Sample Z- Test & & Hypothesis Two \\
\hline N & & 40 \\
Normal Parameters & & \\
& Mean & 2.5500 \\
Most Extreme Differences & Std. Deviation & .98580 \\
& Absolute & .312 \\
& Positive & .312 \\
& Negative & -.188 \\
Z-Test & & 1.970 \\
Asymp. Sig. (2-tailed) & & .001 \\
\hline
\end{tabular}




\begin{tabular}{|c|c|c|}
\hline & & Hypothesis Two \\
\hline $\mathrm{N}$ & & 40 \\
\hline \multirow[t]{2}{*}{ Normal Parameters ${ }^{\mathrm{a}}$} & Mean & 2.5500 \\
\hline & Std. Deviation & .98580 \\
\hline \multirow[t]{3}{*}{ Most Extreme Differences } & Absolute & .312 \\
\hline & Positive & .312 \\
\hline & Negative & -.188 \\
\hline$Z$ - Test & & 1.970 \\
\hline Asymp. Sig. (2-tailed) & & .001 \\
\hline
\end{tabular}

Source: SPSS Output

From the SPSS output, it will be observed that Z-test calculated is 1.970 while $Z$ critical is 1.6448536 . Since the critical value at 1.6448536 is less than the calculated Z (1.970), the null hypothesis will be rejected and the alternative accepted. This implies that; The qualification of audit committee member affects its report

HYPOTHESIS 111

Ho: Audit committee multiple directorship do not positive effect on the function of the committee

Table 4.2.3

\begin{tabular}{|l|l|l|}
\hline RESPONSES & NO & PERCENTAGE \\
\hline Agree & 5 & $10.5 \%$ \\
\hline Disagree & 19 & $47.5 \%$ \\
\hline Strongly Agree & 10 & $25 \%$ \\
\hline Strongly Disagree & 6 & $15 \%$ \\
\hline Total & 40 & 100 \\
\hline
\end{tabular}

Sources: Researcher's Survey 2013

The table of response was subjected to analysis using SPSS (16) and the Z-Test result is given below:

One Sample Z-Test

Source: SPSS Output

\begin{tabular}{|ll|l|}
\hline & & Hypothesis Three \\
\hline N & & 40 \\
& Mermal Parameters & \\
& Std. Deviation & 2.4250 \\
Most Extreme Differences & Absolute & .90263 \\
& Positive & .281 \\
& Negative & .281 \\
Z-Test & & -.194 \\
Asymp. Sig. (2-tailed) & & 1.778 \\
a. Test distribution is Normal. & & .004 \\
\hline
\end{tabular}

From the SPSS output, it will be observed that Z-test calculated is 1.778 while $\mathrm{Z}$ critical value is 1.6448536. Since the critical value at 1.64485 is less than the calculated $Z$ (1.778), the null hypothesis will be rejected and the alternative accepted. This implies that; Audit committee multiple directorship have positive effect on the function of the committee

\subsection{Disccussion Of Findings}

Having presented the statistical analysis of our results, we hereby present our findings:

1. Users significantly agreed that the inclusion of the audit committee report in the financial statement significantly affects the quality of financial reporting. This finding was in line with that of Anyaduba (2006) who asserts that audit committee impact significantly on corporate governance thus, improving reporting quality and also slightly related to that of Okpala et al (2012) who was of the view that the integrity of financial statements of public limited companies depends on the degree of audit committee's activities but went contrary to that of Enofe Aronmwan \& Abadua, 2013 who asserts that the inclusion of the audit committee report in the financial statement does not significantly improve the financial reporting quality an organization and should not be a compulsory report so as to reduce cost, waste and make the financial statement brief yet weighty and relevant.

2. The qualification of audit committee members, according to users' perception, adds to the quality of the financial statement. Users believe that audit committee members knowledge in accounting and in-depth 
understanding of financial reporting enhances the relevance of their report hence, may be argued not to be duplication of efforts. This view is in line with Song \& Windram (2000) who said that the Financial literacy reduced fraud in corporate financial reporting and also with the Sarbanes-Oxley Act (2002) which requires each public listed company to disclose whether or not it has a financial expert in the audit committee.

3. Audit committee multiple directorship have positive effect on the function of the audit committee. The opposite has been the view and standpoint Song \& Windram (2000) that asserts that multiple directorship may cause limitations of time and commitment for audit committee members from performing effectively, whereas the findings were in line with that of Ruzaidah \& Takiah (2004), they argued that multiple directorships of audit committee members was found to have significant positive relationship with corporate social reporting practices and corporate performance and also in line with that of Adeyemi, Okpala \& Dabor (2012) who were of the opinion that multiple directorship of audit committee members is a significant factor in explaining audit quality in Nigeria this might be due to the appointment of experienced directors as audit committee members.

\section{Conclusion}

We have examined the role of audit committee in enhancing financial reporting in Nigeria. In the first section, we stated the research problems, objectives, as well as hypotheses to be tested. Next, we reviewed relevant literature on the subject matter. Furthermore, our research methodology, design, presentation, and analysis of results were highlighted. From the work done, it is safe to say that the composition of audit committee affects its report as the audit committee report in itself is relevant, the qualification of audit committee members, according to users' perception, adds to the quality of the financial statement. And that Audit committee multiple directorship have positive effect on the function of the audit committee.

\subsection{Recommendations}

In light of the foregoing discussions, it is our opinion and recommendation that the following should be put in place since the audit committee report is seen as to significantly affect the quality of financial reporting, it should not be a compulsory report so as to reduce cost, waste and make the financial statement brief yet weighty and relevant. The Nigeria law is silent on the issue of qualification of audit committee members. However, it was discovered from the analysis that audit committee members knowledge in accounting and in-depth understanding of financial reporting and practice is a prerequisite for users before relying on their reports as such the Nigeria law should try as much as possible to revisit their qualifications of Audit committee member to add some basic qualification requirements just as the Sarbanes-Oxley Act (2002) which requires each public listed company to disclose whether or not it has a financial expert in the audit committee. Also on the issue of audit committee multiple directorship its findings is subjective to different companies. However from the selected companies on this research, they were of the ideal that the experience audit committee members gained through director positions in other companies when brought in to the new companies enhances their quality of decision making, hence quality of financial reporting. However companies who wished to adopt this method should check for time management of such member so as not cause limitations of time and commitment for audit committee members from performing effectively.

\section{References}

[1]. Anyadoda Obi, (April/June 1996), "The Institute of Chartered Accountants of Nigeria News: Financial Statements: Still a Long Way to go", Lagos Nigeria: Quarterly journal of The Institute of Chartered Accountants of Nigeria Publication.

[2]. Anyaduba, J. O. (2006). The Impact of Audit Committee on Corporate Governance Practices in Nigeria, Benin Journal of Social Sciences.

[3]. Armitage, J. L., \& Bradley, R. J. (1994). Audit Committees: Quarterly journal of The Nigerian Accountant.

[4]. Ayinde, I. (2002). Audit committee: History and Evolution. Presented at a National Seminar on

[5]. Enhancing Audit Committee Effectiveness, Organized by ICAN, Lagos.

[6]. Adeyemi. S.B, Okpala. O. \& Dabor .L. (2012) Factors Affecting Audit Quality in Nigeria International Journal of Business and Social Science (3) 20 [Special Issue - October 2012

[7]. Companies and Allied Matters Act (2004) Investment and Security Act: (2009) Princeton Educational Service: Lagos.

[8]. Companies and Allied Matters Act (1990): Official Gazette, (77) 2, Federal Government

[9]. Printer, Lagos.

[10]. Cutforth E. Arthor Sir, (1907) "Audit" London: Gee and Company Limited

[11]. Enofe A.O; Aronmwan E.J \& Abadua H.S. (2013) Audit Committee Report in Corporate Financial Statements: Users' Perception in Nigeria European Journal of Accounting Auditing and Finance Research. (1) 1, March 2013 Published by European Centre for Research Training and Development UK (www.ea-journals.org)

[12]. Ekueme C. Sam, (April/June" Auditing -Bridging The Expectation Gap" Lagos Nigeria: Quarterly journal of The Institute of Chartered Accountants of Nigeria Publication.

[13]. Finance Committee on Corporate Governance [FCCG] (1999). Report on Corporate Governance, Malaysia, Ministry of Finance

[14]. Kenneth .E.O. (2012) Audit Committee and Integrity of Financial Statements: A Preventive Mechanism for Corporate Failure. Australian Journal of Business and Management Research (2) 8 November-2012 ISSN.

[15]. Millichamp, A.H (1978) “Auditing” (Guernsey, Channel Island: The Guernsey Press company Limited).

[16]. Muhamad-Sori, Z., Abdul-Hamid, A. I., Mohd-Saad, S. S., \& Evans, J. E. (2007). Audit Committee Authority and Effectiveness: The Perceptions of Malaysian Senior Managers. International Research Journal of Finance and Economics, (8). 
[17]. Nnadi S. Godson, (October/December, 1999) “: The Institute of Chartered Accountants of Nigeria News-Making Audit Committee Effective" Lagos Nigeria: Quarterly journal of The Institute of Chartered Accountants of Nigeria Publication.

[18]. Ruzaidah, R. \& Takiah, M.I. (2004). The Effectiveness of Audit Committee in Monitoring the Quality of Corporate Reporting, A Chapter in Corporate Governance: An International Perspective. MICG Publication.

[19]. Shivdasani, A. (1993). Board Composition, Ownership Structure and Hostile Takeovers, Journal of Accounting and Economics, (16).

[20]. Song, J \& Windram, B (2000). The Effectiveness of Audit Committee: Experience from UK, Working Paper. 12th Asian-Pacific Conference on International Accounting Issues. Beijing. China. 21-24, October.

[21]. Sir Robert Smith (2003) Audit Committees Combined Code Guidance Report And Proposed Guidance by an FRC-appointed group. The Financial Reporting Council Limited: London

[22]. United States Congress (2002), "The Sarbanes-Oxley Act of 2002", Paper Presented at $107^{\text {th }}$

[23]. Congress of the United States of America, H.R. 3763, Government Printing Office, Washington, DC.

[24]. Urbancic, F. R. (2001). The Usefulness of Audit Committee Reports: Assessment and Perceptions. The Journal of Applied Business Research, (7) 3 . 